DOI 10.37882/2223-2982.2021.04.39

\title{
ПОЭЗИЯ КАК СПОСОБ РАННЕГО РАЗВИТИЯ ДЕТЕЙ. МЕТОДИКА СИНТЕЗА СТИХОТВОРЕНИЙ И КАРТИННО-ГРАФИЧЕСКИХ ОБРАЗОВ
}

\section{POETRY AS A WAY OF EARLY CHILDHOOD DEVELOPMENT. METHODS OF SYNTHESIS OF POEMS AND GRAPHICS}

\section{Iurkova}

Summary: The article reveals the features of poetry and the role of memorizing poems in the context of the method of early childhood development, the formation of the functions of coherent speech, in particular, using the memorization technique according to picture and graphics. In addition, the article reveals the importance of poetry in the formation of a child's personality and harmonious development.

Keywords: poetry, memory, technique, early childhood development, children's literature, poems, intellectual abilities.
Юркова Мария Викторовна Независимый исследователь mmariia@inbox.ru

Аннотация: Статья раскрывает особенности поэзии и роли заучивания стихотворений в контексте способа раннего развития детей, становления их функций связной речи, в частности при помощи методики заучивания по картинно-графическим схемам. Помимо этого, статья раскрывает значение поэзии в становлении личности ребенка, ее гармоничного развития.

Ключевые слова: поэзия, память, методика, раннее развитие, детская литература, стихотворения, интеллектуальные способности.

ное произведение. Для ребенка данные характеристики крайне важны и привлекательны, потому, в основе своей, все дети любят стихотворения и интуитивно тяготеют к ним. Стихотворения наделены еще и таким завораживающим ребенка компонентом, как рифма. Ее четкость, емкость, но, в то же время, простота и мелодичность, дает ребенку возможность усвоить стихотворение и начать воспроизводить его достаточно быстро.

Ребенок имеет способность к распознаванию ритмов с рождения, но существуют утверждения, что и во внутриутробном периоде он уже может отличать речь по ее темпо-ритму, в особенности, если будущая мама общается со своим малышом и читает ему стихотворения.

Каждый ребенок имеет свои любимые стихотворения. Они имеют настолько сильное влияние на малыша, что посредством их воспроизведения возможно влиять на настроение ребенка и корректировать его негативные проявления. Иногда достаточно начать рассказывать знакомое и любимое стихотворение, и ребенок возвращается в свое естественное и привычное состояние. В процессе неоднократного воспроизведения стихов и частого возвращения к поэзии, ребенок не просто механически повторяет слова, но и различает настроение, которое передает произведение, а также начинает понимать смысл, который оно несет.

Очень многие педагоги прибегают в практике воспитания к тому, что стимулируют ребенка к заучиванию стихотворений. Это, в действительности, является очень 
хорошим тренировочным процессом для когнитивной сферы малыша. Когда он манипулирует с разным дидактическим материалом, в том числе и с игрушками, задействуется левое полушарие его мозга. При заучивании стихотворение активизируются оба полушария мозга ребенка одновременно.

Безусловно, важным критерием в интеграции поэзии как инструмента раннего развития детей, необходимо ориентироваться на литературу, которая подходит ребенку по возрасту. Самым маленьким детям, в основном, предложены стихотворения, которые содержат не более четырех строк и повествуют о любимых предметах малыша. Для детей постарше стихотворения становятся объемнее и уже затрагивают какие-либо узконаправленные тематики - повествуют о животных, окружающей среде, жизни и деятельности сказочных персонажей. Важное условие, которое необходимо соблюдать - нельзя заставлять ребенка слушать или воспроизводить стихотворения. Задача педагога - дать возможность малышу соприкоснуться с поэзией таким образом, чтобы у него сформировалось трепетное и влекущее чувство к ней. Ребенок должен оценить красоту и мелодичность поэзии, впитывать культуру языка, научатся оценивать его мелодичность и красоту. Все это возможно лишь в условиях ненасилия и не навязывания, а личного трепета и тяготения ребенка к поэзии.

Помимо эстетического развития личности, стихотворения имеют прикладной характер. Так, они содержат достаточно обширное число аллитераций, т.е. повторений звуков, что способствует формированию и развитию артикуляции ребенка, и последующему правильному произношению слов и предложений.

Еще К.Д. Ушинский отмечал, что научение ребенка пяти ранее неизвестным ему словам станет долгим и мучительным процессом, но стоит облечь двадцать таких слов в единую систему и подкрепить картинками - и процесс усвоения станет мгновенным. В действительности, овладение языком становится ключевой задачей раннего развития ребенка. Словарь необходим ему для попытки построения коммуникации со взрослыми и сверстниками, а также для дальнейшего успешного обучения в школе. Согласно К.Д. Ушинскому, серьезным инструментом в развитии речи детей является именно литературный язык, который становится источником обогащения и развития у ребенка навыка коммуникации [2].

В действительности, для того чтобы добиться точности речи ребенка, ее выразительности и содержательности к младшему школьному возрасту, необходимо делать упор на работу с поэзией, а именно - на заучивание стихотворений. Они способствуют быстрому запоминанию, в отличие от прозы, содержат глубокие поэтические образы, которые стимулируют воображение ребен- ка, его способность к ассоциациям. Стихотворная форма расширяет кругозор ребенка, позволяет ему знакомиться с миром окружающей действительности в наиболее эстетической манере. Посредством поэзии ребенок усваивает богатые образцы родной речи, а также получает эмоциональное удовлетворение от произведения. Эти образцы различны по своему воздействию: в них дети познают лаконичность и точность слова, улавливают музыкальность, напевность поэтической речи, замечают её ритмическую и метрическую организованность, созвучие стихотворных строк.

Итак, самым действенным приемом развития речи и когнитивных функций ребенка - заучивание стихотворений. С легкостью усваивать стихи могут дети, которые обладают развитой памятью. Под этим мы подразумеваем, что ребенок способен усвоить объем информации и сделать это в достаточно короткие сроки. Но, помимо этого, важным показателем становится то, насколько точно ребенок усвоил выученное и как долго он может хранить эту информацию в памяти для последующего воспроизведения.

У дошкольников память носит непроизвольный характер: они лучше запоминают факты, предметы, явления события, близкие их жизненному опыту. Память ребёнка - дошкольника развивается постепенно. С возрастом увеличивается роль опосредованной памяти. Чем старше становится ребёнок, тем большее количество материала усваивается именно благодаря этому виду памяти [5]. С 5 лет уже можно развивать опосредованную память, которая представляет собой особую деятельность ума, специально направленную на запоминание чего-либо, и связанную с использованием особых приемов запоминания.

Для того, чтобы ребенок впитывал эстетику поэзии и тем самым тренировал свои интеллектуальные способности, развивал когнитивные функции, предлагается методика заучивания стихотворений с помощью картинно-графических схем. Она достаточно действенна потому, что делает акцент на воображении и ассоциативном мышлении ребенка, ведь, как известно, дети легче запоминают ту информацию, которая наделена очень конкретным и ярким образом. Прослушивая и заучивая стихотворение, ребенок «изображает» его содержание в своих мыслях, ассоциирует себя с его героями и переносит вымышленные образы на предметы окружающей его среды. Таким образом, данное мысленное «проживание» произведения помогает ребенку осмыслять его. Стихотворения, которые имеют такие характеристики как лаконичность, предметность и образность, лучше запоминаются ребенку, в том числе, за счет того, что он переживает их сюжет внутри себя [2].

Для раннего развития детей посредством поэзии 
используются короткие произведения, которые содержат много существительных и глаголов, а также обладают динамично развивающимся сюжетом. Для того, чтобы стихотворение было лучше усвоено, используются иллюстрации, которые сопровождают стихотворение. Для начала ребенку предоставляется возможность создать образ в своем воображении, но далее он может быть подкреплен визуальным материалом, который подкрепляет аудиальный канал восприятия. Таким образом, происходит запоминание сразу по нескольким каналам восприятия, что развивает мыслительный процесс ребенка.

Ключевая особенность такой методики состоит в том, что иллюстрация служит подспорьем для воображения ребенка, раскрывает смысл стихотворения, акцентирует его внимания на ключевых фразах, помогая держать их в памяти. Для того, чтобы развивать мышление ребенка, взрослый может объединять несколько иллюстраций под одно стихотворение - в таком случае, упор сделан на зрительную ассоциацию сюжета на картинке и его перенос на стихотворение.

В обратном случае, возможно объединять несколько стихотворений для заучивания под одну иллюстрацию здесь происходит построение внутреннего образа и сюжета, который переносится на изображение.

Впоследствии, иллюстрации можно не демонстрировать ребенку вовсе - в момент речевого воспроизведения им стихотворения, происходит воспроизведение образа или иллюстрации посредством мыслительного процесса. Таким образом, задействуются оба полушария головного мозга ребенка, тренируется память, образное и ассоциативное мышление, развиваются речевые функции [1].

Таким образом, посредством визуальных компонентов - картинок и иллюстраций - происходит материализация образа произведения. Благодаря этому ребенок может с легкостью воспроизвести ход стихотворения, фокусировать внимание на его компонентах, что, в це- лом, повышает процесс запоминания и делает его более эффективным.

Итак, посредством синтеза стихотворений и картинно-графических иллюстраций, дети учатся метафорично мыслить, обогащают свою речь образами, грамматическими конструкциями, используют широкий синонимичный ряд. Все это оказывает влияние на когнитивные процессы ребенка, а также гармонично развивает его личность.

Применяя описанную методику, становится возможным приобщить к авторским стихотворениям даже тех детей, которые испытывают трудности с запоминанием и воспроизведением информации. Это станет фундаментом для формирования их долгосрочной памяти, а также поспособствует формированию речевых функций.

\section{Выводы}

Поэзия по своей природе насыщенна образами, разнообразна с точки зрения фонетики, динамичная и яркая. Для ребенка все эти характеристики очень привлекательны, поэтому он тяготеет к ней, хочет стать частью эстетически прекрасного.

Как правило, поэзия для детей имеет легкие рифмы, четкие и мелодичные, которые прекрасно поддаются запоминанию. Процесс заучивания стихотворений для детей - это инструмент раннего развития когнитивных функций ребенка и прекрасная тренировка для мозга: расширяется кругозор, рифма дает возможность обрести внутреннюю гармонию, развивается память, формируется культурный уровень. Каждое словесное произведение, усвоенное памятью ребенка, обогащает словарный фонд, формирующий его собственную речь. Выразительность исполнения развивает технику речи: дикцию, дыхание. Поэзия учит любить и помогает увидеть прекрасное и необычное в простой жизни, посмотреть другими глазами на то, что нас окружает.

\section{ЛИТЕРАТУРА}

1. Алексеева М.М., Яшина В.И. Методика развития речи и обучения родному языку дошкольников: Учеб. пособие для студ. высших и сред. пед. учеб. заведен - М.: Издательский центр «Академия», 2006. - 400 с.

2. Бурачевская 0.В. Развитие связной речи детей дошкольного возраста с общим недоразвитием речи посредством заучивания стихов / 0.В. Бурачевская, Н.И. Бурачевская. — Текст : непосредственный // Педагогика: традиции и инновации : материалы VII Междунар. науч. конф. (г. Челябинск, январь 2016 г.). - Челябинск : Два комсомольца, 2016. — C. 82-85. — URL: https://moluch.ru/conf/ped/archive/186/9462/ (дата 0бращения: 22.02.2021).

3. Крупенчук О.И. Стихи для развития речи. - СПб., 2004.

4. Лебедева И.Н. Развитие связной речи дошкольников. Обучение рассказыванию по картине. — СПб.: ЦДК проф. Л.Б. Баряевой, 2009.

5. Щукина Г.И. Проблема познавательных интересов в педагогике. - М.: Просвещение, 2010. - 351 с.

(с) Юркова Мария Викторовна (mmariia@inbox.ru). 